\title{
Comparative biochemical study of iron, zinc and copper status in healthy and diabetic rats fed diets containing antinutritional factor and sugar substitutes
}

\author{
Fares K. Khalifa, Amal A. Ahmed, Mona A. Sadek and \\ Amira A. Abd El-Hamid \\ Biochemistry and Nutrition Department \\ Faculty of Girls, Ain Shams University, Cairo, Egypt
}

\begin{abstract}
The present work conducted to study some trace elements status (iron, zinc and copper) in diabetic and healthy non-diabetic rats consuming balanced diets containing phytate (as a factor inhibiting minerals absorption) at a tested dose of 1 $\mathrm{g} / 100 \mathrm{~g}$ diet alone or incorporated with sorbitol or mannitol (as sugar substitutes) at a tested dose of $15 \mathrm{~g} / 100 \mathrm{~g}$ diet. The experiment included 64 male albino rats which were classified into four healthy and four diabetic groups. To achieve these objectives, the present study included the following three main points (1) Determination of blood hemoglobin $(\mathrm{Hb})$, erythrocytes superoxide dismutase activity (SOD), plasma glucose and ferritin levels. (2) Determination of catalase enzyme activity and iron $(\mathrm{Fe})$, zinc $(\mathrm{Zn})$, and copper $(\mathrm{Cu})$ contents in liver. (3) Evaluation of fecal levels of iron, zinc and copper. The results indicated that, the fecal levels of the studied three measured trace elements were significantly higher in both healthy and diabetic rats fed on different tested diets. Plasma glucose levels, erythrocytes SOD and liver catalase activities showed marked improvements in diabetic rats consumed sorbitol or mannitol when compared to rats fed on diets containing phytate alone. The presence of sugar substitutes not affected significantly the levels of blood $\mathrm{Hb}$ and plasma ferritin. Antinutritional factor either alone or associated with sorbitol or mannitol reduced the storage levels of iron in liver. The tested sugar alcohols showed slight effects on zinc and copper.
\end{abstract}

Key words: Copper, Diabetes rats, Iron, Mannitol, Phytate, Sorbitol, Zinc.

\section{INTRODUCTION}

Iron, copper, and zinc are essential elements for the maintenance of life and health ${ }^{(\mathbf{1 , 2})}$.They are components of vital substances and many enzyme systems ${ }^{(3-5)}$. Iron is a component of hemoglobin, myoglobin $^{(6)}$, cytochromes a,b and c, as it plays an essential role in oxygen transport and cellular respiration. Moreover, iron is involved with zinc in many metabolic mechanisms ${ }^{(7,8)}$. Zinc is an essential element required for insulin functions ${ }^{(\mathbf{9})}$, neuropeptidases and many enzymes such as DNA polymerase, RNA polymerase and superoxide dismutase $^{(\mathbf{1 0})}$. Zinc containing enzymes are essential for growth ${ }^{(\mathbf{1 1})}$, wound healing, reproductive function and immune system. Zinc plays a role in the protection from free radical, which is involved in various 
peroxidative processes ${ }^{(\mathbf{1 2})}$. Copper is essential trace element which induces specific function in carbohydrates and lipid metabolism ${ }^{(\mathbf{1 3})}$ and has a biological role against free radical active processes. The trace elements copper and zinc are linked together in systolic defense against reactive oxygen and nitrogen species. Copper, zinc-superoxide dismutase catalyzes the dismutation of superoxide to oxygen and hydrogen peroxide ${ }^{(14)}$.

Several previous studies showed that phytate is an efficient inhibitor of absorption of essential dietary minerals such as copper, zinc and iron (15).The anionic character of phytate makes it ideal for forming complexes with mineral elements ${ }^{(\mathbf{1 6}, \mathbf{1 7})}$, which is regarded as a natural antioxidant ${ }^{(\mathbf{1 8})}$ since it decreases the catalytic reactivity of transition metals ${ }^{(\mathbf{1 9})}$. Diabetes mellitus is a group of metabolic disorders, the incidence of which varies widely throughout the world. The treatment of diabetes mellitus includes insulin, anti-diabetic agents and dietary regimens ${ }^{(\mathbf{2 0})}$. Although the emphasis on macronutrients intakes, there is a strong evidence that there is an abnormal metabolism of several micronutrients individual. Zinc is one of the essential micronutrients of which status and metabolism is altered in that condition. Polyols, natural hydrogenated sugars (sugar alcohols) are used as alternative sweeteners which as they have the same role of artificial sweeteners but with safety $^{(21)}$. These sugar alcohols including sorbitol and mannitol are used as sugar substitutes in many dietetic foods and as a drug vehicle ${ }^{(22}$, 23). Sorbitol and mannitol are used to replace sucrose in food products and may lower the postprandial rise in glucose $^{(24)}$. The aim of the present study was evaluation of iron, zinc, and copper status in diabetic and healthy rats fed diets containing sorbitol or mannitol as sugar substitutes.

\section{MATERIALS \& METHODS}

\section{MATERIALS:}

1-Phytate: Pure sodium phytate powder was obtained from Roubinal Company for Chemicals, Egypt. It was added at the level of $1 \mathrm{~g} / 100 \mathrm{~g}$ diet according to Lopez et al., ${ }^{(25)}$.

2-Alcoholic Sugars: Two types of sugar alcohols (sorbitol and mannitol) were obtained from El-Gomhoria Company for Chemicals and Drugs, Egypt. The two tested sugar alcohols were added at the level of $15 \mathrm{~g} / 100 \mathrm{~g}$ diet according to Shaker et al., (26).

3- Animals: The experimental animals used throughout the work were adult male albino rats (SpragueDawley strain) weighting $100 \pm 5 \mathrm{~g}$, supplied from the Animal House of El-Salam farm, Giza, Egypt.

4-Experimental diets: The experimental diets used were the balanced diets prepared according to $A I N^{(27)}$.

\section{METHODS:}

Experimental Design: Throughout the study, a total number of 64 male albino rats were used. The animals were divided into two sections. The first one included healthy rats $(n=32)$ and the second included diabetic rats $(n=32)$. The baseline blood sugar level in all diabetic rats was about 200 $\mathrm{mg} / \mathrm{dl}$. The healthy normal rat groups (from G1 to G4) were offered balanced diets and treatments as 
follows: Group (1); healthy control (HC) was fed balanced diet, Group (2): was fed balanced diet $+1 \%$ phytate, Group (3): was fed balanced diet $+1 \%$ phytate $+15 \%$ sorbitol and Group (4): was fed balanced diet $+1 \%$ phytate $+15 \%$ mannitol. The corresponding diabetic rat groups (from 5 to 8) were offered balanced diets and treatments as follows: Group (5); diabetic control (DC) was fed balanced diet (DC), Group (6): was fed balanced diet $+1 \%$ phytate, Group (7): was fed balanced diet $+1 \%$ phytate $+15 \%$ sorbitol and Group (8): was fed balanced diet $+1 \%$ phytate $+15 \%$ mannitol. Water was provided ad libitum. Rats randomly housed individually with constant environments in controlled stainless steel cages; temperature $25^{\circ} \mathrm{C} \pm 5^{\circ} \mathrm{C}$, humidity $50 \% \pm 10 \%$, and light dark cycle held constant 12/12 hrs. All rats offered a balanced diet for 4 days as adaptation period on the environmental conditions before starting the experiment. The experimental period was 4 weeks during which body weight of rats and food intake were recorded weekly to monitor the body weight changes. At the end of experimental period, and after overnight fasting rats were sacrified under ether anesthesia. Blood samples were collected from the hepatic portal vein into two-dry clean centrifuge tubes containing ethylene diamine tetracetic acid (EDTA) as anticoagulant. The first blood samples were used immediately for determination of hemoglobin, while the other tubes were left at room temperature, and the plasma was separated by centrifugation at 1500 r.p.m. for 15 minutes. After separation of plasma the red blood cells were washed twice with cold saline and an aliquot of packed cells were diluted with cold distilled water, then the ethanol-chloroform extract was prepared for the assay of superoxide dismutase activity in erythrocytes. Plasma was used for the determination of blood glucose and ferritin levels. Liver was separated, rinsed and washed with saline solution, then blotted on filter paper. About $0.4 \mathrm{~g}$ of liver from each rat was separated for the determination of catalase enzyme activity and the residue of liver was dried, ground and then stored frozen at $-20^{\circ} \mathrm{C}$ until analyzed for zinc, copper and iron contents. Feces were collected daily for each group in the last week of the experiment, dried and kept at $-20^{\circ} \mathrm{C}$ for determinations of fecal measurements.

\section{Fecal measurements:-}

Fecal dry weights (g) were recorded and fecal minerals (iron, zinc, and copper) were determined in feces by using atomic absorption spectrophotometer according to Lopez et al. ${ }^{(25)}$.

\section{Blood measurement:-}

Hemoglobin concentration was determined according to the method described by Crosby et al., (28) using Sorin hemoglobin kit.

Erythrocyte measurement:-

Determination of superoxide dismutase activity:-

The determination of superoxide dismutase (SOD) activity based on the ability of the enzyme to inhibit the reduction of nitroblue tetrazolium (NBT) by the superoxides generated by the reaction of photo reduced riboflavin and oxygen as the method described by Winterbourn et al. ${ }^{(29)}$. 
The unit of SOD activity is defined as the enzyme causing half the maximum inhibition of NBT reduction.

Plasma Measurements:-

Plasma level of glucose was determined by enzymatic colorimetric method according to Trinder $^{(30)}$ by Elitech Diagnostic kit, France. Plasma ferritin was determined by using a monoclonal antibody-based enzyme immunoassay according to Ellis $^{(31)}$ using Sorin kit.

\section{Liver Measurements:-}

Catalase activity was determined by the method described by Maehly and Chance, ${ }^{(32)}$.All the procedure steps were carried out at $4^{\circ} \mathrm{C}$. Liver tissue was homogenized in $\mathrm{M} / 15$ phosphate buffer solution, then centrifuged at 5000 r.p.m. for 15 minutes. The extraction was washed twice with cold buffer (5ml each time). The combined supernatants were used for the assay. One unit of catalase activity is the amount of enzyme, which liberates half the peroxide oxygen from a hydrogen peroxide solution of any concentration in 100 second at $25^{\circ} \mathrm{C}$. Iron (Fe), Zinc $(\mathrm{Zn})$, and Copper $(\mathrm{Cu})$ were determined in liver by atomic absorption spectrophotometer (Pye Unicam, model 929) according to Lopez et al., (25).

Statistical analysis: Statistical analysis was done by completely randomized design in factorial arrangement (ANOVA, F-test, L.S.D.), according to Steel and Torrie, ${ }^{(33)}$.

\section{RESULTS}

The results of the study are summarized in tables ( $1 \& 2$ ) and figures (1-3)

\section{DISCUSSION}

The results presented in table (1) show the fecal dried weight and the fecal contents of iron, zinc, and copper. It is clear that the fecal dry weight increased when rats consumed either phytate alone or in association with sorbitol or mannitol compared with their healthy and diabetic controls. The levels of minerals in feces were significantly increased in both healthy and diabetic rats which fed on diets containing phytate either alone or with sorbitol or mannitol. These results agreed with the results of dried weights of feces which recorded significant increases. Also these results agree with those of Hayashi et al., (10) who reported that phytic acid had a very marked inhibitory effect on the rate of absorption of minerals specially zinc and iron. Lopez et al., ${ }^{(25)}$ recorded that phytic acid reduced iron and copper absorption. These findings also confirmed the finding of Oberleas, ${ }^{(34)}$ that showed the major effect of phytic acid on trace elements especially for zinc is on the reabsorption of endogenously secreted zinc. It is clear from table(1) that the levels of iron in feces were increased in diabetic control (DC) group and the percentage of increments was $+3.52 \%$, while the levels of zinc and copper were decreased by about $-11.47 \%$ and $20.33 \%$ respectively compared with healthy control group (HC). The results of the present study also showed that, the concentrations of the three trace elements in feces were markedly decreased in rats using sorbitol or mannitol when compared 
with corresponding groups fed on diets containing phytate alone in both healthy and diabetic rats. The present findings agree with the results of Hara et al., ${ }^{(35)}$ who reported that, the presence of fermentable sugars enhanced microbial fermentation and increase trace elements bioavailability. On the other hand, the pathway conversion of the sugar alcohol to fructose may increase intestinal fermentable matter which might increase the bioavailability of micronutrients.

Table (2) illustrates the plasma levels of glucose $(\mathrm{mg} / \mathrm{dl})$ and ferritin (ng/ml), blood hemoglobin (g/dl), erythrocytes superoxide dismutase (SOD) activity (U/ml) and the activity of catalase enzyme in liver (IU/100g tissue).The results of the present study showed that the levels of glucose in plasma were significantly decreased in diabetic rats which fed on diets containing phytate either alone or with sorbitol or mannitol when compared with diabetic control group $\left(G_{5}\right)$. The percentage decrease in plasma glucose level in diabetic rats fed on phytate sorbitol diet $\left(\mathrm{G}_{7}\right)$ was much more than that of phytate mannitol diet $\left(\mathrm{G}_{8}\right)$. This reduction effect of sorbitol or mannitol might be due to the fact that these sugar alcohols are absorbed relatively slow and produce less postprandial hyperglycemia. Recent studies on phytate have shown its beneficial effects such as decrease in blood lipids, decrease in blood glucose response and cancer risk ${ }^{(\mathbf{1 9})}$. The present results confirmed and agree with the results of Gupta et al. ${ }^{\text {(36) }}$ who postulated that diabetic rats showed increases by about 3.4 fold in plasma glucose levels compared to control normal rats. The current findings are in agreement with the comparison of Akgun and Ertel ${ }^{(37)}$ that studied the effect of sucrose, sorbitol, and fructose on plasma glucose and insulin requirement in diabetic and normal subjects. The mean peak increment in plasma glucose was highest after the sucrose meals, lowest after sorbitol meals and intermediate after fructose meals. In addition, Shaker et al. ${ }^{(26)}$ demonstrated that when diabetic rats consumed sugar alcohols sorbitol and mannitol they showed significant reduction in blood glucose levels and explained that effect by the slow rate of absorption of sugar alcohols from the gut. With respect to hemoglobin levels, the percentage decrease in hemoglobin level for DC group was $2.55 \%$ compared with the HC one. When phytate presented in diet either alone or in association with sorbitol or mannitol, it decreased significantly $(p<0.01)$ the values of blood Hb levels in either healthy or diabetic groups. El-Hendy et al. ${ }^{(38)}$ found that feeding phytate rich food led to zinc deficiency and affected negatively the hematological parameters including blood hemoglobin, total erythrocytes count and packed cell volume. Plasma ferritin levels reflected the iron status in case of healthy and diabetic animals consuming phytate alone or in association with sugar alcohols. In general, levels of stored heme were affected significantly by the presence of phytate as antinutritional factor results in decreasing the values either in healthy or diabetic rats. The present results are in agreement with those of Lopez et al. ${ }^{(25)}$ who reported that the inhibitory effect of phytate on iron 
absorption are reflected by a decrease in blood iron and ferritin by $12 \%$ and $31 \%$ respectively. On the other hand, the presences of sugar alcohols don't affect significantly the levels of plasma ferritin. In the current study, it is likely that phytate and sorbitol or mannitol in combination act in a synergistic manner through highly significant decrease in blood hemoglobin levels in all diabetic groups when compared with healthy ones.

With respect to the oxidative stress processes, the activities of erythrocytes SOD and liver catalase enzymes indicated that, the presence of phytate alone in healthy rats decreased significantly the SOD activity by about $-14.49 \%$ and catalase activity by $-35.54 \%$ compared to HC group. Also, in diabetic rats fed on diet containing phytate alone, the percentage decrease in SOD and catalase activities were $24.02 \%$ and $-29.67 \%$ respectively. These results are similar to the findings of Milne and Johnson ${ }^{(39)}$, who noticed that the inhibitory effect of antinutritional factors on copper status are reflected by decrease on the activity of erythrocytes SOD. Arora and Gones $^{(40)}$ reported that both zinc and copper are responsible for $\mathrm{Cu}-\mathrm{Zn}$ superoxide dismutase stability and activity, and the decrease in their plasma concentrations might result in the decrease in SOD activity. On the other hand, by using sorbitol or mannitol in different diets, there was remarkable improvement in the activities of SOD and catalase in both healthy and diabetic groups. The values of catalase activity, which inhibits peroxidation processes and its level affected by zinc and copper status, showed a significant increase in rats fed on diets containing sorbitol or mannitol when compared to those fed diets containing phytate alone.

Figures 1, 2 and 3 illustrate the liver contents of iron, copper and zinc. As regard to liver iron, the results showed that the liver contents of diabetic rats were not affected significantly when compared to healthy control group. While in contrast the presence of antinutritional factor as phytate either alone or associated with sorbitol or mannitol reduced the storage level of iron in liver in case of healthy and diabetic groups compared to healthy control. The percentage decrease was varied between 27.95 - $29.4 \%$ in healthy treated groups and $19.26-26.38 \%$ in diabetic treated groups. Also the levels of zinc and copper are affected significantly by addition of antinutritional factor either alone or associated with sorbitol or mannitol. Similar to these, Van Hauwelingen et $\boldsymbol{a l}^{(\mathbf{( 4 1 )}}$ indicated that, copper deficiency because of phytate effect on its absorption, significantly lowered copper concentration in plasma and tissues of rats. In conclusion, sorbitol and mannitol significantly restored iron, zinc, and copper absorption which was reduced in healthy and diabetic rats fed diets containing phytate as an antinutritional factor. 
Table (1): Effects of the different diets consumed on fecal dry weight (g) and fecal minerals content (mg/100g).

\begin{tabular}{|c|c|c|c|c|c|c|c|c|c|}
\hline \multirow{2}{*}{$\begin{array}{l}\text { Groups } \\
\text { Fecal } \\
\text { Measurements }\end{array}$} & \multicolumn{4}{|c|}{ Healthy consumed balanced diet } & \multicolumn{4}{|c|}{ Diabetic consumed balanced diet } & \multirow[b]{2}{*}{$\begin{array}{l}\text { L.S.D. } \\
(\mathbf{0 . 0 1 )}\end{array}$} \\
\hline & $\begin{array}{c}\text { Control } \\
\text { (HC) }\end{array}$ & +Phytate & $\begin{array}{l}\text { +Phytate } \\
\text { \& Sorbitol }\end{array}$ & $\begin{array}{c}\text { +Phytate } \\
\text { \& Mannitol }\end{array}$ & $\begin{array}{l}\text { Control } \\
\text { (DC) }\end{array}$ & +Phytate & $\begin{array}{l}\text { +Phytate } \\
\text { \& Sorbitol }\end{array}$ & $\begin{array}{c}\text { +Phytate } \\
\text { \& } \\
\text { Mannitol } \\
\end{array}$ & \\
\hline $\begin{array}{l}\text { Dried weight } \\
\text { (g/day) }\end{array}$ & $6.68 \pm 0.13$ & $10.89 \pm 0.19$ & $10.59 \pm 0.18$ & $10.60 \pm 0.04$ & $6.76 \pm 0.11$ & $11.21 \pm 0.05$ & $10.42 \pm 0.05$ & $10.41 \pm 0.03$ & 0.28 \\
\hline -\% change from $\mathrm{HC}$ & & +63.02 & +58.53 & +58.68 & +1.19 & +67.81 & +55.98 & +55.83 & \\
\hline Iron (mg/100g) & $64.04 \pm 0.01$ & $95.23 \pm 0.05$ & $80.9 \pm 0.11$ & $77.26 \pm 0.03$ & $66.3 \pm 0.05$ & $90.82 \pm 0.07$ & $84.82 \pm 0.07$ & $79.7 \pm 0.02$ & 4.23 \\
\hline$-\%$ Change from $\mathrm{HC}$ & & +48.7 & +26.32 & +20.64 & +3.52 & +41.81 & +32.44 & +24.45 & \\
\hline Zinc (mg/100g) & $17.08 \pm 0.02$ & $24.99 \pm 0.03$ & $21.25 \pm 0.15$ & $20.08 \pm 0.02$ & $15.12 \pm 0.04$ & $21.63 \pm 0.05$ & $21.65 \pm 0.08$ & $20.80 \pm 0.18$ & 3.40 \\
\hline -\%Change from HC & & +46.3 & +24.41 & +17.56 & -11.47 & +26.63 & +26.75 & -21.77 & \\
\hline Copper (mg/100g) & $1.77 \pm 0.02$ & $3.04 \pm 0.01$ & $2.97 \pm 0.05$ & $2.72 \pm 0.05$ & $1.41 \pm 0.02$ & $2.51 \pm 0.05$ & $2.50 \pm 0.05$ & $2.49 \pm 0.02$ & 0.24 \\
\hline -\%Change from HC & & +71.75 & +67.79 & +53.67 & -20.33 & +41.80 & +41.24 & +40.67 & \\
\hline
\end{tabular}

Values expressed as mean \pm S.E.

HC: Healthy control; DC: Diabetic control. 
Table (2): Effects of the different diets consumed on blood hemoglobin (g/dl), plasma ferritin (ng/ml), erythrocyte superoxide ismutase (SOD) activity, liver catalase activity and plasma glucose (mg/dl).

\begin{tabular}{|c|c|c|c|c|c|c|c|c|c|}
\hline \multirow{2}{*}{$\begin{array}{l}\text { Groups } \\
\text { Parameters } \\
\end{array}$} & \multicolumn{4}{|c|}{ Healthy consumed balanced diet } & \multicolumn{4}{|c|}{ Diabetic consumed balanced diet } & \multirow{2}{*}{$\begin{array}{l}\text { L.S.D. } \\
(0.01)\end{array}$} \\
\hline & $\begin{array}{c}\text { Control } \\
\text { (HC) }\end{array}$ & +Phytate & $\begin{array}{l}\text { +Phytate } \\
\text { \& Sorbitol }\end{array}$ & $\begin{array}{c}\text { +Phytate } \\
\text { \& Mannitol }\end{array}$ & $\begin{array}{c}\text { Control } \\
\text { (DC) }\end{array}$ & +Phytate & $\begin{array}{l}\text { +Phytate } \\
\text { \& Sorbitol }\end{array}$ & $\begin{array}{c}\text { +Phytate } \\
\text { \& Mannitol }\end{array}$ & \\
\hline Hemoglobin (g/dl) & $15.29 \pm 0.49$ & $10.21 \pm 0.84$ & $10.15 \pm 0.49$ & $10.23 \pm 0.77$ & $14.9 \pm 0.66$ & $9.97 \pm 0.75$ & $9.58 \pm 0.52$ & $9.23 \pm 0.25$ & 2.36 \\
\hline -\%Change from HC & & -33.22 & -33.61 & -33.09 & -2.55 & -34.79 & -37.34 & -39.63 & \\
\hline Ferritin (ng/ml) & $18.1 \pm 1.32$ & $10.31 \pm 0.96$ & $11.09 \pm 0.88$ & $10.42 \pm 0.76$ & $14.47 \pm 0.66$ & $14.71 \pm 0.95$ & $13.69 \pm 0.68$ & $13.37 \pm 0.77$ & 2.71 \\
\hline -\%Change from HC & & -43.03 & -38.72 & -42.43 & -20.05 & -18.72 & -24.36 & -26.13 & \\
\hline $\begin{array}{l}\text { Erythrocyte } \\
\text { superoxide dismutase } \\
\text { (SOD) (U/ml blood) } \\
\text {-\%Change from HC }\end{array}$ & $245.61 \pm 8.73$ & $\begin{array}{c}210.00 \pm 14.7 \\
-\mathbf{1 4 . 4 9} \\
\end{array}$ & $\begin{array}{c}239.11 \pm 13.9 \\
-\mathbf{2 . 6 4}\end{array}$ & $\begin{array}{c}233.00 \pm 13.9 \\
-\mathbf{5 . 1 3} \\
\end{array}$ & $\begin{array}{c}272.23 \pm 10.8 \\
+\mathbf{1 0 . 8 3} \\
\end{array}$ & $\begin{array}{c}186.60 \pm 18.1 \\
-\mathbf{2 4 . 0 2}\end{array}$ & $\begin{array}{c}223.81 \pm 15.6 \\
\mathbf{- 8 . 8 7} \\
\end{array}$ & $\begin{array}{c}228.19 \pm 19.1 \\
-7.09 \\
\end{array}$ & 28.72 \\
\hline $\begin{array}{l}\text { Catalase } \\
\text { (IU/100g tissue) }\end{array}$ & $322.16 \pm 3.27$ & $207.66 \pm 3.21$ & $310.00 \pm 7.73$ & $298.11 \pm 13.1$ & $300.14 \pm 2.35$ & $226.55 \pm 2.35$ & $264.91 \pm 2.44$ & $266.20 \pm 2.11$ & 20.78 \\
\hline -\% Change from HC & & -35.54 & -3.76 & -7.59 & -6.82 & -29.67 & -17.77 & -17.37 & \\
\hline Glucose (mg/dl) & $85.69 \pm 3.98$ & $98.47 \pm 2.3$ & $93.71 \pm 4.01$ & $94.36 \pm 3.95$ & $285.93 \pm 12.2$ & $236.93 \pm 17.1$ & $222.2 \pm 13.3$ & $235.18 \pm 5.2$ & 45.75 \\
\hline -\% Change from HC & & +14.91 & +9.35 & +10.11 & +233.6 & +236.93 & +159.3 & +174.4 & \\
\hline
\end{tabular}

Values expressed as mean \pm S.E; HC: Healthy control; DC: Diabetic control. 

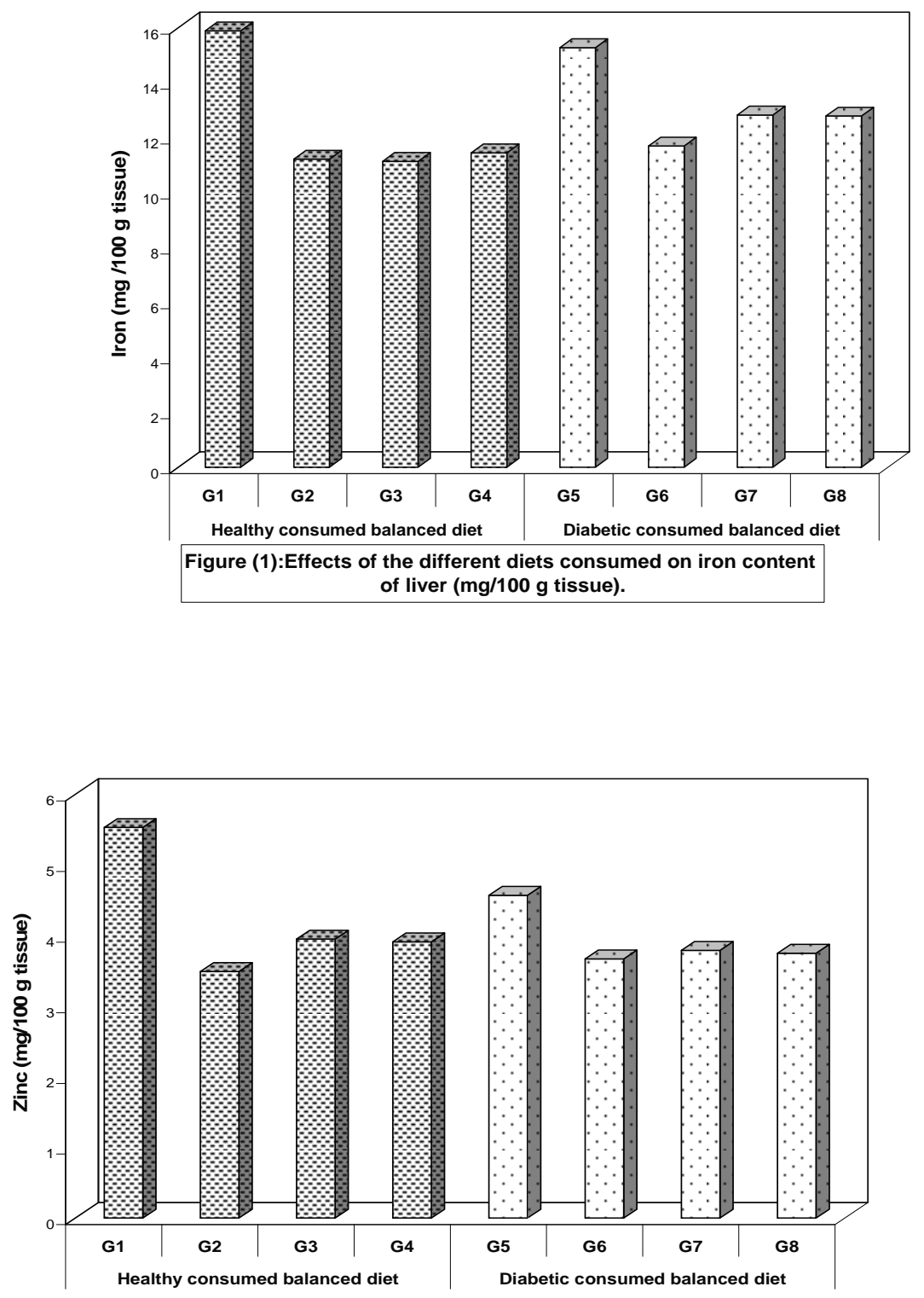

Figure (2): Effects of the different diets consumed on zinc content of liver (mg/100 g tissue) 


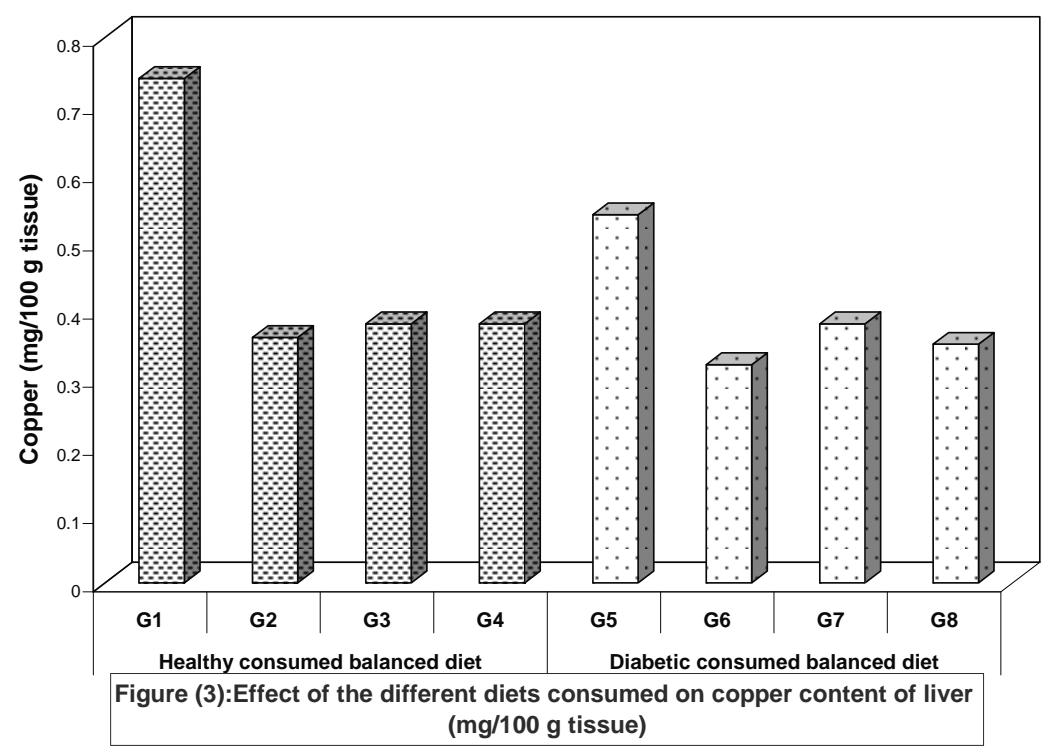

\section{REFERENCES}

1. Hambidge, M., Cousing, R.J. and Costello, R.B. (2000): Zinc and health: current status and future directions. J.Nutr., 130: 1341S-1343S.

2. Walker, C.F., Kordas, K., Stoltzfus, R.J. and Black, R.E. (2005): Interactive effects of iron and zinc on biochemical and functional outcomes in supplementation trails. Am.J. Clin. Nutr., 82: 5-12.

3. Hambidge, M. (2003): Biomarkers of trace minerals intake and status. Am. Soc. Nutr. Sci., 133: 948S-955S.

4. Tocheva,E.I., Rosell, F.I. and Mauk, A. G. (2004): Structure of copper-containing enzymes. Science 304: 867-870.

5. Jacquillet, G., Barbier, O., Cougnon, $M$. and Tauc, $M$. (2006): Zinc protects renal function during cadmium intoxication in the rat. Am.J. Physiol. Renal Physiol., 290: F127-F137.

6. Dominiczak, M.H. and Broom, I. (2005): Micronutrients: vitamins and minerals.In: Medical Biochemistry, $2^{\text {nd }}$ edition, pp.139-141. Baynes, JW and Dominiczak,MH, Elsevier Mosby, London, New York,Sydney, Toronto.

7. Donangelo, C.M.; Woodhouse, L.R., and King, S.M. (2002): Supplemental zinc lowers 
measures of iron status in young women with low iron reserves. J.Nutr., 132:1860-1864.

8. Rosado, J.L. (2003): Zinc and copper: Proposed fortification levels and recommended zinc compounds. J.Nutr., 133: 2985S2989S.

9. Salgueiro, M.J., Kerbs, N., Zubbillaga, M.B., Weill, R., Postaire, E., Lysionek, A.E., Caro, R.W., Paoli, T.D., Hager, A. and Boccio, J. (2001): Zinc and diabetes mellitus. Is there a need of zinc supplementation in diabetes mellitus. Biol. Trace Elem. Res., 81: 215-228.

10. Hayashi,K., Hara, H., Asvarujanon, P. and Aoyama, Y. (2001): Ingestion of insoluble dietary fiber increased zinc and iron absorption and restored growth rate and zinc absorption suppressed by dietary phytate in rats. Br. J. Nutr., 86: 443-451.

11. Manary, M.J., Hotz, C., Krebs, N.F., Gibson, R.S. and Westcott, J.E. (2002): Zinc homeostasis in Malawian children consuming a highphytate, maize-based diet. Am.J.Clin.Nutr., 75: 1057-1061.

12. DiSilvestro, R.A. (2000): Zinc in relation to diabetes and oxidative disease. J.Nutr., 130: 1509S-1511S.

13. 13.Cooper, G.J., Chan, Y.K., Dissanayake, A.M., Leahy, F.E. and Keogh, G.F. (2005): Demonstration of a hyperglycemia driven pathogenic abnormality of copper homeostasis in diabetes and its reversibility by selective chelation. Diabetes 54: 14681476.

14. Klotz, O.L., Kroncke, K.D., Buchczyk, D.P. and Sies, $H$. (2003): Role of copper, zinc, selenium and tellurium in the cellular defense against oxidative and nitrosative stress. J.Nutr., 133: 1448S-1451S.

15. Adams, C.L., Hambidge, M., Raboy,V. and Sian,A. (2002): Zinc absorption from a lowphytic acid maize. Am.J.Clin.Nutr., 76:556-559.

16. Spears, J.W. (2003: Trace minerals bioavailability in ruminants. J.Nutr.,133:1506S1509S.

17. Mazariegos, M., Hambidge, K.M., and Krebs, N.F. (2006): Zinc absorption in Guatemalan schoolchildren fed normal or low phytate maize. Am.J.Clin.Nutr., 83(1):59-64.

18. Muraoka, $S$. and Miura, T.(2004): Inhibition of xanthine oxidase by phytic acid and its antioxidative action. Life Sci., 13:1691-1700.

19. Shi, J., Arunasalam, K., Yeung, D., Kakuda, Y. and Mitta, G. (2004): Phytate from edible beans: chemistry, processing and health benefits. Food Agri. Environ., 2:49-58.

20. American Diabetes Association (ADA) (2006): Standards of medical care in diabetes. Diabetes care 29:4-24

21. Oyama,T., Miyasita,Y., Watanabe, $H$. and Shirai, $K$. (2006): The role of polyol pathway in high glucose-induced endothelial cell damages. 
Diabetes Res. Clin. Pract., 73: 227-234.

22. Obrosova, I.G. (2005): Increased sorbitol pathway activity generates oxidative stress in tissue site for diabetic complications. Antioxid. Redox Signal 7: 1543-1552.

23. Federici, $M$. and Lauro, $R$. (2005): Review article: diabetes and atherosclerosis-running on a common road. Aliment Pharmacol.Ther., 2:11-15.

24. Howard, B.V. and Rosett, J.W. (2002): Sugars and cardiovascular disease: The role of dietary fructose, sorbitol, and mannitol. Circulation 106: 523.

25. Lopez, H.W., Coudray, C., Levrat-Verny, M.A., FeilletCoudray, C., Demigne, C. and Remesy, C. (2000): Fructooligosaccharides enhance mineral apparent absorption and counteract the deleterious effects of phytic acid on mineral homeostasis in rats. J.Nutr. Biochem., 11:500-508.

26. Shaker, A.M., Abdel Fattah, S.S., Attia, A.M. and Labeib, F. (1997): Effect of sugar alcohols fed to Albino rat on serum glucose and lipid components. Egyptian J. Nutr., 12:1-16.

27. American Institute of Nutrition (AIN) (1977): Report of the AIN Ad Hoc Committee on standards for nutritional studies. J. Nutr. 107:1340-1348.

28. Crosby, W.H., Munn, J.I. and Furth, F.W. (1954): Standardizing a method for clinical hemoglobinometry. U.S.
Armed Forces Med.J., 5:693699.

29. Winterbourn, C.C., Hawkins, R. E., Brain, M. and Carell, R.W. (1975): The estimation of red cell superoxide dismutase activity. J. Lab. Clin. Med., 85: 337-341.

30. Trinder, P. (1969): Determination of glucose in blood using glucose oxidase with an alternative oxygen acceptor. Ann.Clin.Biochem.,6: 24-27

31. Ellis, D. (1979): Serum ferritin compared with other indices of iron status in children and teenagers undergoing maintenance hemodialysis. Clin. Chem., 25:741-744.

32. .Maehly, A.C. and Chance, B. (1954): The assay of catalase and peroxidases in: "Methodes of Biochemical Analysis "Glick, D. (Ed). Vol. 1, Interscience Publishers, Inc, New York PP. 357-424.

33. Steel, R.J. and Torrie, J. H. (1980): Principles and procedures of statistics (20Ed.) McGraw Hill Book Co., New York.

34. Oberleas, D, (1996): Mechanism of zinc homeostasis. J. Inorg. Biochem. 62:231-241.

35. Hara,H., Konishi, A. and Kasai,T.(2000): Contribution of the cecum and colon to zinc absorption in rats. J. Nutr., 130: 83-89.

36. Gupta, D., Raju, J., Prakish, J.R and Baquer, C.N.Z. (1999): Change in the lipid profile, lipogenic, and related enzymes in the livers of 
experimental diabetic rats: effect of insulin and vanidate. Diabetic Res. and clinical practice 46:1-7.

37. Akgun, S., and Ertel, N.H. (1980): A comparison of carbohydrate metabolism after sucrose, sorbitol, and fructose meals in normal and diabetic subjects. Diabetic Care 3: 582585.

38. El-Hendy, H.A., Yousef, M.I. and El-Naga, N.I. ((2001): Effects of dietary zinc deficiency on hematological and biochemical parameters and concentrations of zinc, copper, and iron in growing rats. Toxicology 167(2): 163-70.
39. Milne, D.B., Johnson, P.E. (1993): Assessment of copper status: effect of age and gender on reference ranges in health adults. Clin. Chem., 39:883-887.

40. Arora, A.S. and Gones, G. J. (1996): The role of metals in ischemia-reperfusion injury of the liver. Semin. Liver Dis., 16:31-38.

41. Van Houwelingen, F., Van den Berg, G.J., Lemmens, A.G., Sijtsma, K.W. and Beynen, A.C. (1993): Iron and zinc status in rats with diet-induced marginal deficiency of vitamin A and/or copper. Biol. Trace Elem. Res., 38(1): 83-95. 


\section{دراسة بيوكيميائية مقارنة عن مستوى الحديد والزتك والنحاس فى الفئران

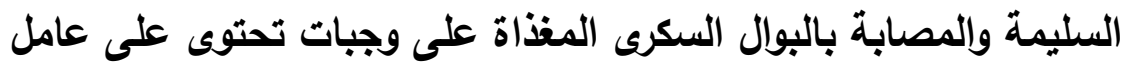 \\ غذائى مضاد ويدائل سكرية}

$$
\text { فاس خبري خليفه- أمل عشعاوي أحمد- مني أحمد صادق - أمبره عبد الرحمن عبد الحمبي }
$$

قسم الكيمياء الحيوية والتغذية-كلية البنات- جامعة عين شمس

أجريت هذه الدراسة لمعرفة حالة بعض المعادن النادرة ( الحديد - الزنك- النحاس) فى الفئران المصابة بالبوال السكرى ومقارنتها بالفئران السليمة والنى تغذت على وجبات منات متوازنة تحتوى على الفيتات ( كعامل

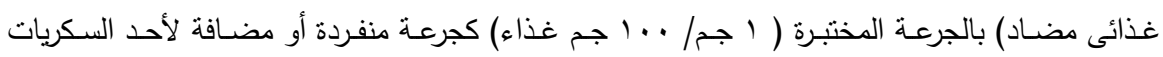

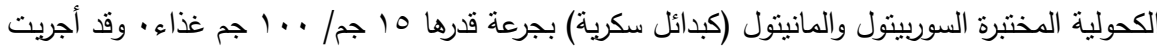

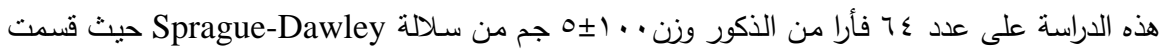

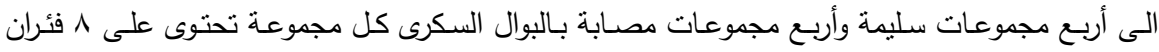

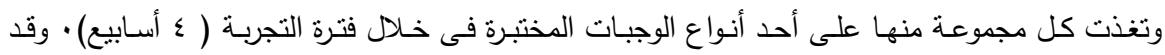

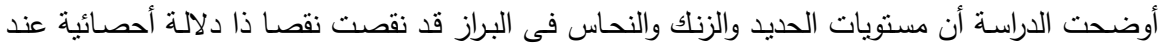
تناول الفينات فى الغذاء سواء كجرعة منفردة أو بالأشتراك مع السوريبتول أو المانيتول فى كل من الفئن الفئران

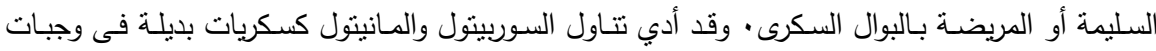

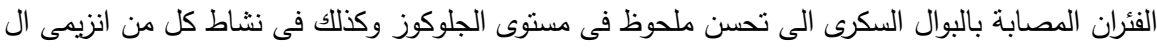

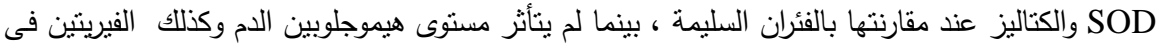

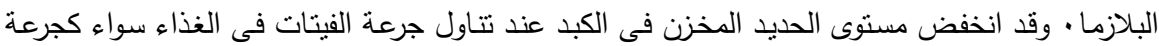

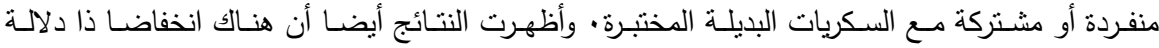

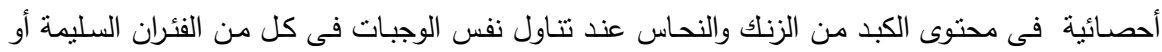

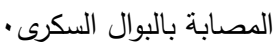

